\title{
Sustainability in the automotive industry, importance of and impact on automobile interior - insights from an empirical survey
}

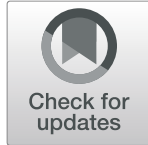

\author{
Wanja Wellbrock ${ }^{1 *}$, Daniela Ludin ${ }^{1}$, Linda Röhrle $^{1}$ and Wolfgang Gerstlberger ${ }^{2}$
}

\begin{abstract}
Sustainability is currently one of the main issues in all media and in society as a whole and is increasingly discussed in science from different sides and areas. Especially for the automotive industry, sustainability becomes more and more important due to corporate scandals in the past and topics such as electric motors, lightweight construction and $\mathrm{CO} 2$ emission reduction are key issues. Although the focus is primarily on other components, the interior cannot be neglected either in terms of sustainability. Interior is the most frequently seen part of the car by the driver. Therefore, e.g. the use of natural fibres especially for premium brands can only be considered in connection with highest standards regarding practical and aesthetical aspects. Consequently, the following research question arises: How do the three pillars of sustainability (economical, ecological and social issues) influence interior development at premium brand manufacturers and how do customers accept sustainable solutions? The focus of the paper is exclusively on premium brands due to the higher spread of sustainability effects compared to volume brands. A quantitative study is carried out to determine the expectations on the customer side regarding more sustainability in the automotive industry in general and in the interior sector in particular and to derive corresponding challenges and potentials for original equipment manufacturers.
\end{abstract}

Keywords: Sustainability, Automotive industry, Interior, Innovation

\section{Introduction}

Sustainability is regarded as the keyword of the twentyfirst century and the importance of the topic is not yet sufficiently widespread (Mittelstaedt, Shultz II, Kilbourne, \& Peterson, 2014). The associated topic of resource conservation, which has been important since the eighteenth century, is now more relevant than ever. Above all, the automotive industry, which is the most important branch of industry in terms of turnover and the growth engine for Germany, has to deal more intensively with sustainable development and the associated

\footnotetext{
* Correspondence: wanja.wellbrock@hs-heilbronn.de

The paper was presented at the $8^{\text {th }}$ ICSR Conference - International Conference on Sustainability and Responsibility, Cologne, $15^{\text {th }}$ of November 2018

${ }^{1}$ Heilbronn University of Applied Sciences, Campus Schwäbisch Hall, Faculty of Management and Sales, Heilbronn, Germany

Full list of author information is available at the end of the article
}

effects and challenges. Automotive manufacturers are under pressure to comply with both political guidelines and internal specifications, as well as with constantly changing individual customer wishes (Thun \& Hoenig, 2011; Wallentowitz \& Leyers, 2014).

For the automotive industry, topics such as electric motors and the associated optimization areas, lightweight construction and $\mathrm{CO}_{2}$ emission reduction are key issues. Nevertheless, the car's interior cannot be ignored. After all, the interior is the part of a car most frequently seen by the driver and must therefore be practical, aesthetically pleasing and at the same time weight saving. The use of natural fibres as alternative materials in the interior plays an important role and is a further step towards greater sustainability (Pischinger \& Seiffert, 2016).

Consequently, the following central research question arises: How is the new development of the interior by 
premium brand manufacturers influenced by the three pillars of sustainability (economical, ecological and social issues) and what are the challenges for original equipment manufacturers (OEMs) and suppliers? The contribution focuses exclusively on the German premium manufacturers Audi, BMW, Mercedes-Benz and Porsche, since sustainability at these companies is already more integrated into the manufacturing process.

Based on a literature review on sustainability in the automotive industry, previous efforts to increase sustainability in the interior sector will be elaborated on. Subsequently, an empirical study is used to determine the expectations on the customer side regarding more sustainability in the automotive industry in general and in the interior sector in particular and to derive corresponding challenges and potentials for OEMs and suppliers.

\section{Sustainability in the automotive industry}

Long-term success in the automotive industry is primarily achieved through consistent innovation strategies, strong branding, global efficiency in the value chain and qualified and motivated employees. Research and development can be argued as the key to long-term success after all, no other industry invests more than the automotive industry in this area. Currently, the automotive industry is arguably witnessing the greatest phase of upheaval in its history. Mega trends such as emission reduction, lightweight construction, automated driving, connectivity and mobility services have changed the landscape for good. In line with these trends, the supplier industry is also adapting and undergoing fundamental changes (Dannenberg, 2017; Koers, 2014; Pischinger \& Seiffert, 2016).

The topic of sustainability in the automotive industry is also gaining more momentum in the scientific community. Nunes and Bennett, for example, carry out a fundamental comparison of environmental initiatives of automobile manufacturers, conclude that these are often still very vague, and require further concretization. Another criticism is that the focus is primarily on the ecological dimension (Nunes \& Benett, 2010). Azevedo et al. develop a theoretical framework for analysing the influence of green and lean SCM practices on the sustainable development of automobile manufacturers. Ecological (e.g. $\mathrm{CO}_{2}$ emissions), social (e.g. supplier screening) and economic (e.g. operating costs) aspects are considered as performance indicators (Avezedo, Carvaho, Duarte, \& Cruz-Machado, 2012). Azevedo and Barros complement this with an analysis of a sustainable business model for the automotive industry that integrates all three dimensions of sustainability. This contribution also shows that there has been a clear improvement in sustainability performance in the automotive supply chain over the last decade (Avezedo \& Barros, 2017). Sinha et al. emphasize that sustainability management in the automotive industry is only possible through a holistic process approach starting with the conception and continuing right up to the series production of the product. In addition to these rather conceptual contributions, several authors consider concrete materials about their sustainability potential for the automotive industry (Sinha et al., 2015). Kumar and Das consider, for example, the suitability of bio composites especially in the field of dashboards (Kumar \& Das, 2016), whereas Dunne et al. focus primarily on the suitability of natural fibres (Dunne, Desai, Sadiku, \& Jayaramudu, 2016). Hetterich et al. consider the specific attitude of motorists towards sustainable materials in the interior sector. The focus here is on the willingness of customers to actually pay more for renewable raw materials (Hetterich, Bonnemeier, Pritzke, \& Georgiadis, 2012).

In sum, the issue of sustainability in the automotive industry may well be gathering momentum and scientific focus, but the interior design sector in particular has been largely neglected. A few papers focus on the topic of sustainable interior, but mostly with a strict technological view (e.g. Bergenwall, Chen, \& White, 2012; Jasiński, James, \& Kerry, 2016; Mayyas, Qattawi, Omar, \& Shan, 2012; Mcauley, 2003; Sopher, 2008; You, Ryu, Oh, Yun, \& Kim, 2006). Some others analyse the potential of sustainability as a customer requirement, but misses the focus on automotive interior (e.g. Biju, Shalij, \& Prabhushankar, 2015; Hetterich et al., 2012; Moisescu, 2018; Panuju, Ambarwati, \& Susila, 2020). The article attempts to close this gap.

\section{Sustainability in the interior of automobiles}

The widespread innovation efforts in the field of electric mobility and autonomous driving also offer the potential to rethink and redesign the car's interior. The vehicle interior has to be transformed into an increasingly attractive living space. This can be achieved, for example, through attractive surfaces made of sustainable materials. The interior plays an increasingly important role in purchasing decisions. It arouses emotions, offers comfort, safety and functionality and radiates brand identity as a fusion (Laukart \& Vorberg, 2016; Pein, Laukart, Feldmann, \& Krause, 2006).

The interior of a vehicle can be divided into six assemblies: the cockpit, the seats, the door and side trim, the headliner, the luggage compartment and the floor trim. The developments in this area is a balancing act between the pressure to innovate and the need to keep costs down. (Dölle, 2013).

\section{Characteristics of natural fibre materials}

Already in 2005, more than 30,000 tons of natural fibres were used in the automotive industry in Europe (Sullins, 
2013). In 2015, the figure was already 50,000 tons, of which ten to $20 \%$ were European hemp fibres. Hemp belongs to the category of baste fibres, which are most frequently used in automotive components. Hemp, kenaf and flax are suitable alternatives to glass fibres because they are less expensive, have a lower density, a high strength and are more environmentally friendly. The use of natural fibres can result in cost savings of ten to 30\% compared to glass fibers. Due to its strength, it can be used as a reinforcement for vehicle interior parts such as door panels. In addition, kenaf, which is cultivated mainly in China and Thailand, has one of the best $\mathrm{CO}_{2}$ absorption rates in the plant world (Adekomaya, Jamiru, \& Sadiku, 2016; Dunne et al., 2016; Suddell, 2008; Sullins, 2013; Verma, Gope, \& Shandilya, 2012).

Another advantage is that the natural fibre-reinforced plastic does not splinter and can break without creating sharp edges. Its low weight and high load-bearing capacity are an advantage for lightweight construction and safety requirements and have a positive influence on crash management. Due to the positive cost performance ratio and the other advantages described, composite materials based on natural fibres have been used for several years for thermoplastics, thermosets and elastomers in automotive interiors. Well-known examples of this are doors made of flax or sisal fibres and polymeric binders such as polypropylene (thermoplastic) or polyurethane (Bjurenstedt \& Lärneklint, 2004; Hull \& Clyne, 1996; Laukart \& Vorberg, 2016).

When selecting alternative materials, great care should be taken. For one, fibres from natural sources are not always more environmentally friendly than conventional fibres. Large amounts of water, pesticides, chemicals and energy are needed to prepare and dye the fabric during cotton degradation and processing. In addition, natural fibre reinforced plastics are neither as strong nor durable as metal or synthetic fibres, so they need to be replaced more frequently, resulting in increased energy consumption in the long term.

Whereas natural fibres were previously concealed behind a thick film lamination, they are now becoming more and more visually perceptible and are increasingly finding their way into the premium interior as a design element. At the same time, suppliers and vehicle manufacturers are in equal demand to conduct even more intensive research in the field of natural fibre-reinforced plastics and to bring technologies to series maturity that make it possible to further increase the proportion of natural fibres in vehicle interiors (Dunne et al., 2016).

\section{Sustainability measures in the interior}

The new hybrid materials and vehicle concepts pose a challenge for manufacturers and suppliers. The lightweight construction required for this should continue to offer the best surfaces in the interior since the appearance conveys a direct impression of quality, which is especially important for premium brands (Dunne et al, 2016; Hassan, Zulkifli, Ghazali, \& Azhari, 2017; Karus \& Kaup, 2002; Puglia, Biagiotti, \& Kenny, 2005). Therefore, corresponding solutions with bio-composite materials are of great importance, as, for example, the supplier Dräxlmaier shows with his Kenaf door trim for the BMW i3 electric vehicle. The component is made exclusively of natural fibre-reinforced polypropylene with functional elements (Bröker \& Ostner, 2017; Gelowicz, Günnel, Hammer, \& Otto, 2017).

The use of natural fibre materials as a design element that underlines the sustainable character of a vehicle was not an option until now. They had not previously met the requirements of OEMs for a high-quality appearance and the technical process conditions of the manufacturers made it difficult to use the materials. After a long development period, the supplier Dräxlmaier and the manufacturer BMW have now joined forces to bring the innovation of visible natural fibres in the interior to series maturity. Requirements for design elements and weight reduction have been met and, at the same time, the materials are ecologically compatible. The "Fast Fibre Forming" developed by Dräxlmaier makes it possible to implement the "Visible Nature". Panels are made of kenaf fibres and coated with a wafer-thin transparent plastic film. The purity of the plant material used ensures a particularly high-quality surface appearance compared to other natural raw material sources such as hemp or flax (Bröker \& Ostner, 2017).

In the BMW i3, the visible door beams and the instrument panel cover are also made of the fibres of the tropical mallow plant Kenaf. The reasons for the selection are that Kenaf has a high degree of fineness and purity of the fibres compared to flax and hemp, which is essential for a high-quality surface. This is an elementary prerequisite because the design philosophy of BMW i vehicles combines a consistent focus on sustainability, which becomes visible and tangible in the interior, with simultaneous fulfilment of the OEM's premium claim (Schmiedel, Barfuss, Nickel, \& Pfeufer, 2014).

A further example is presented by Johnson Controls for the new BMW 3 Series with wood fibre components that not only relieve the burden on the environment but also reduce weight by $20 \%$ compared to solutions previously used (Focus, 2012).

The use of renewable and natural raw materials as a sustainable alternative to plastics is in direct harmony with the needs of the young generation. Yanfeng Automotive Interiors, for example, deliberately presents the recyclable, artistically designed natural fibre middle parts of the door panel in a natural look. According to Han Hendriks, Chief Technology Officer at Yanfeng, there is 
currently a shift towards more personalisation and individualisation. Drivers want to be sustainable and at the same time be safe and in touch with the spirit of the times (Yanfeng, 2017).

The supplier International Automotive Components (IAC) optimizes component designs for OEMs. A new product is the "Fibre Frame" technology. The natural fibre semi-finished product "EcoMatHot" replaces the classic material sheet steel in the mounting frame of the vehicle roof lining with panoramic or sliding roofs. The material consists of $70 \%$ renewable raw materials. A weight reduction of up to $50 \%$ is possible (Industrie, 2017).

In the future, it is expected that the use of renewable raw materials and recycled materials will continue to gain in importance. Visible components made of renewable materials will be found more frequently in the interior of the cars of tomorrow. In this context, the natural materials must be designed haptically and optically so that they can no longer appear only in laminated or mixed form with plastics (Focus, 2012).

\section{Empirical study on customer expectations regarding sustainability aspects in interior design of cars}

Based on the information from the previous chapters an empirical large-volume study is conducted to investigate the expectations and potentials that customers see in sustainability elements, particularly in the interior sector. The empirical survey focuses exclusively on customers of premium brands (Audi, BWM, Mercedes-Benz and Porsche), since sustainability measures are already more widespread in this area and customers have even higher expectations with regard to design and equipment (Skala-Gast, 2012).

\section{Structure of the empirical study}

The empirical study is based on an online survey with purposively selected persons from the Heilbronn University of Applied Sciences, the University of Stuttgart and the company Valeo Schalter und Sensoren in Bietigheim-Bissingen. The survey was conducted via Survey monkey. All persons with a minimum age of 18 years were contacted through the official university or company mailing lists and send on to the questionnaire's homepage. Therefore, the participants were mainly students and employees of the above mentioned Universities and companies. The age limit has been set the minimum age to drive a car in Germany. One hundred forty-one participants fulfilled the desired characteristics, which can be divided in 100 male and 41 female test persons. With regard to premium brands, Audi and Mercedes-Benz each dominated with 34\%,
BMW followed with 25\% and Porsche with almost $7 \%$ of the participants.

The questionnaire consists of 23 questions developed by the authors, divided into three sections: "general sustainability", "specific sustainability in the automotive industry and the interior" and "future expectations".

\section{Empirical results}

The participants of the study recognize the fundamental importance of sustainability. With the exception of two persons, all respondents attach fundamental importance to sustainability in different areas of life. For $81 \%$ the focus is on nutrition, followed by energy supply (66\%) and living (63\%). The area of mobility follows a little behind with $47 \%$ (see Fig. 1). This shows that a fundamental need for sustainability exists, but mobility is not the most important area.

Regarding the question of which factors are decisive when buying a car, quality, price, performance and design are on the first ranks. Sustainability plays an important or even very important role for only $34 \%$ of the respondents, which is the lowest value of all factors (see Fig. 2). This result shows that sustainability is discussed regularly in the automotive industry, but at the same time, it has only a limited influence on customers' purchasing decisions, especially in the premium segment.

The willingness to accept additional costs for sustainable materials in the car is also very indifferent. Almost half of the respondents $(47.5 \%)$ are not prepared to accept higher costs for sustainability aspects in the car. This is quite a high number and shows the problem of automotive manufacturers to transfer additional costs to the customers.

Looking at the single modules of an automobile, power unit (41\%) and electronics (38\%) receive the highest relevance for sustainability from the customer's point of view. For almost $35 \%$, sustainability is important in all areas of the automobile, whereas $30 \%$ highlight especially the interior sector (see Fig. 3). This result demonstrates that although the customer focuses on the sustainability of the interior, at first glance the drive system and electronics in particular have a higher sustainability potential from the customer's point of view. The further investigations now relate exclusively to the interior.

A majority of $74 \%$ of the respondents agree that the OEM should place more emphasis on the selection of sustainable and natural materials in the interior. Only $7 \%$ reject this, which represents a clear message to the OEM.

In order to control the customers' design perception of natural materials in the interior, a picture of an untreated door panel was shown to the participants (see Fig. 4). The reaction to whether the test persons could imagine this in their automobile was very positive. $71 \%$ 


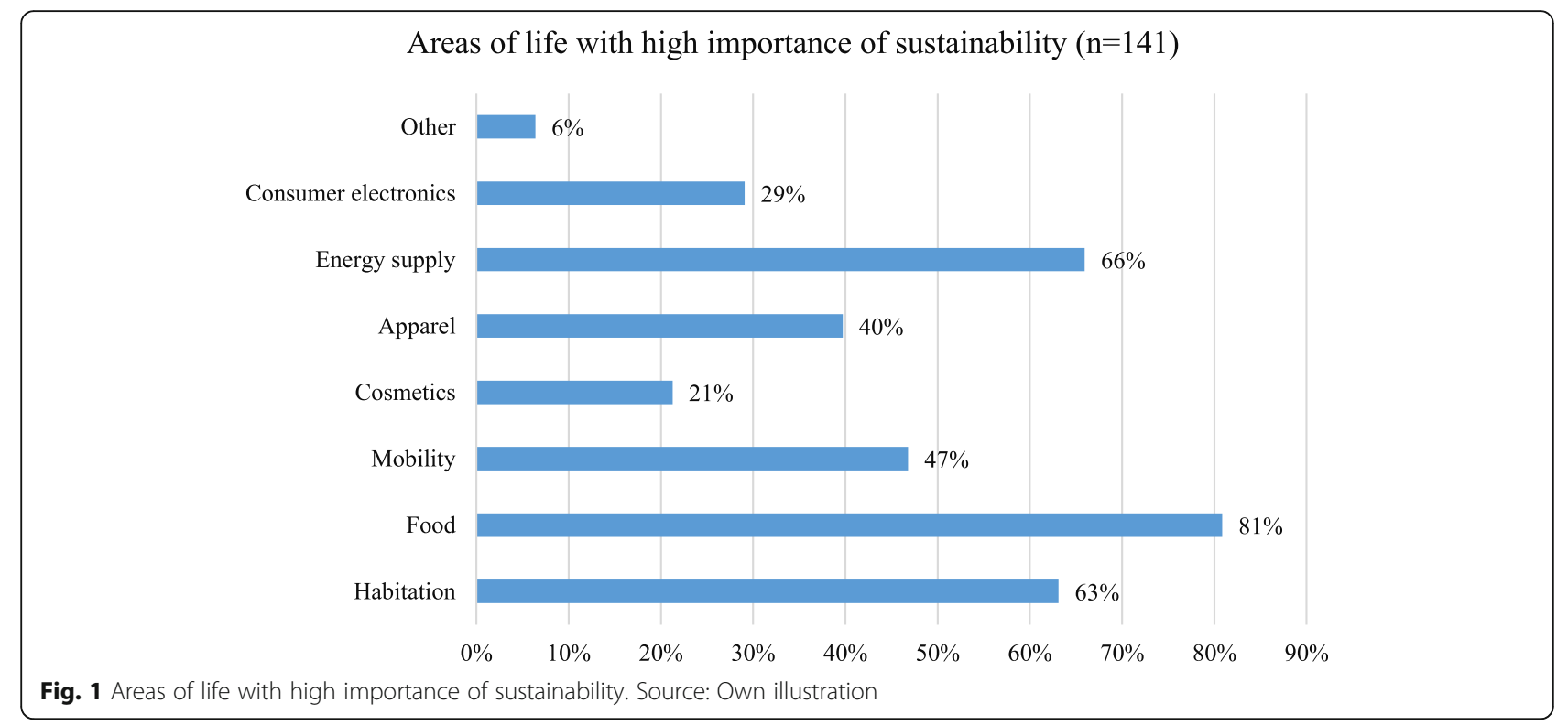

of the respondents could imagine such a door, if properties as haptics, appearance and economy are retained. Only $9 \%$ of the respondents could not imagine such a door.

Looking at additional aspects, which should be fulfilled by sustainable and natural materials in the interior, quality $(74 \%)$ and safety $(71 \%)$ receive the highest percentages, followed by smell and optics (60\%), haptics (57\%) and comfort (55\%). At the end of the scale, individuality only receives $18 \%$, which is surprisingly low compared to the wide variety of variants in the automotive industry (see Fig. 5).

Looking at the individual types of material, it turns out that customers would like to see more sustainable implementations in the interior, particularly for plastics (67\%), textiles (52\%), leather (45\%) and wood (40\%) (see Fig. 6). Especially for the first three materials, sustainable solutions are already available, as described in the previous chapter.

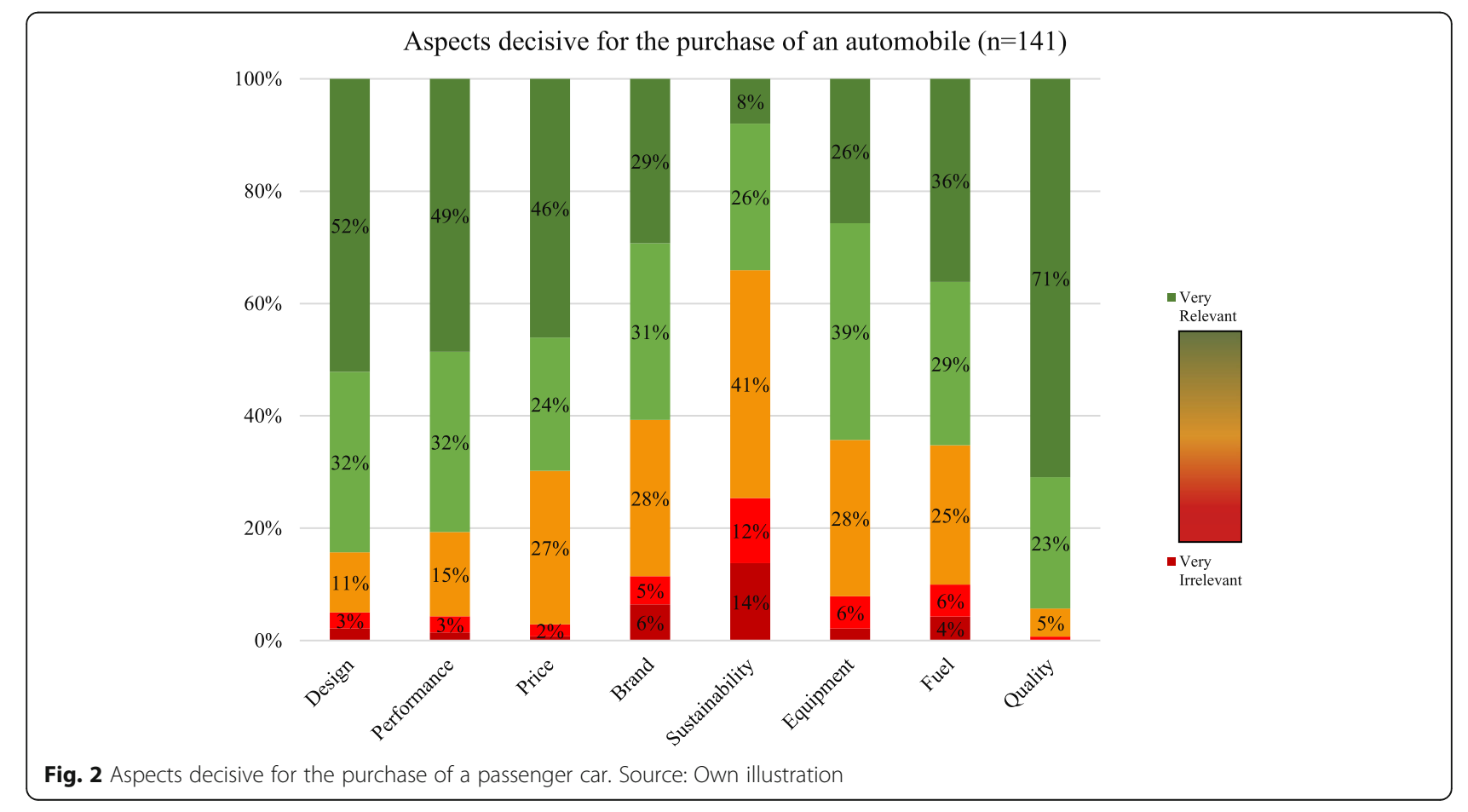




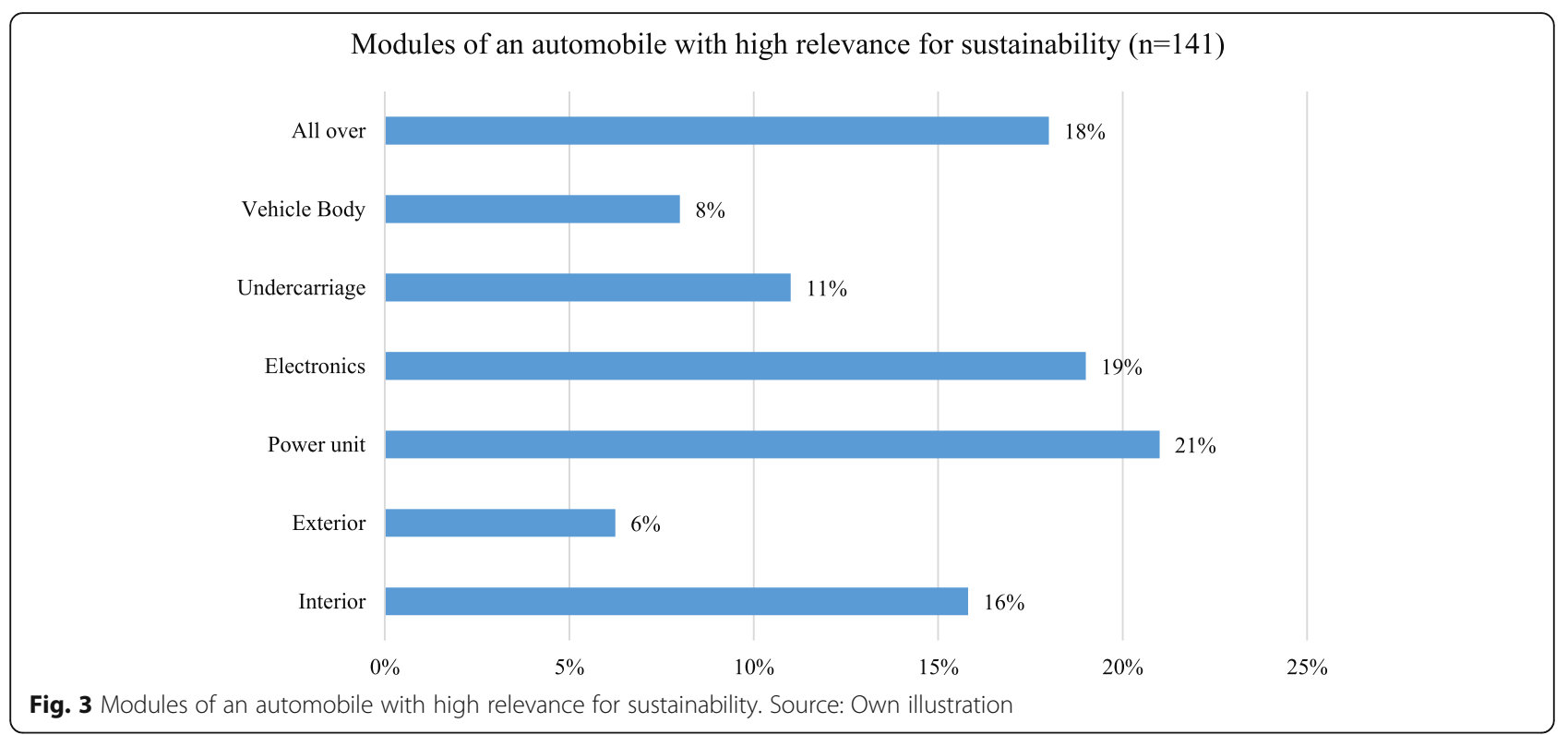

Regarding the variety of natural alternative materials, biomat-plastic (54\%) and recycled material (52\%) receive the highest percentages of people evaluating it as relevant or even very relevant for the interior sector. Overall, all known alternative materials such as ligneous, hemp, kenaf or sisal are well accepted by customers and the percentages for irrelevance are usually much lower for all materials (see Fig. 7).

As an optional question, the participants were asked to decide which material they prefer for which interior component. The blue words are the result of the majority customer decision (see Fig. 8). The results show that the materials selected for the centre console, door trim and decorative elements are already sustainable. Other natural materials such as recycled material or natural rubber also achieve a high level of approval for individual interior components, although they do not yet represent a majority opinion.
The question whether natural materials should be more noticeable in interior design compared to conventional materials also produced a mixed response. $34 \%$ of all participants highlight that natural materials should be noticeable, whereas the same percentage disagree with this statement (see Fig. 9). Therefore, a meaningful picture cannot be derived.

The participants also answered the question whether the usage of natural materials in the interior is a longterm mega trend or only a short-term fashion trend. Only $51 \%$ of the respondents assume it a long-term mega trend, whereas the other half expect only a short fashion trend without long-lasting influence on the automotive industry. Therefore, this question can also be said to paint a much-divided picture.

The final topic is the future relevance of sustainable materials in the interior. Nearly $75 \%$ of the respondents rate the future relevance as very high or at least high,

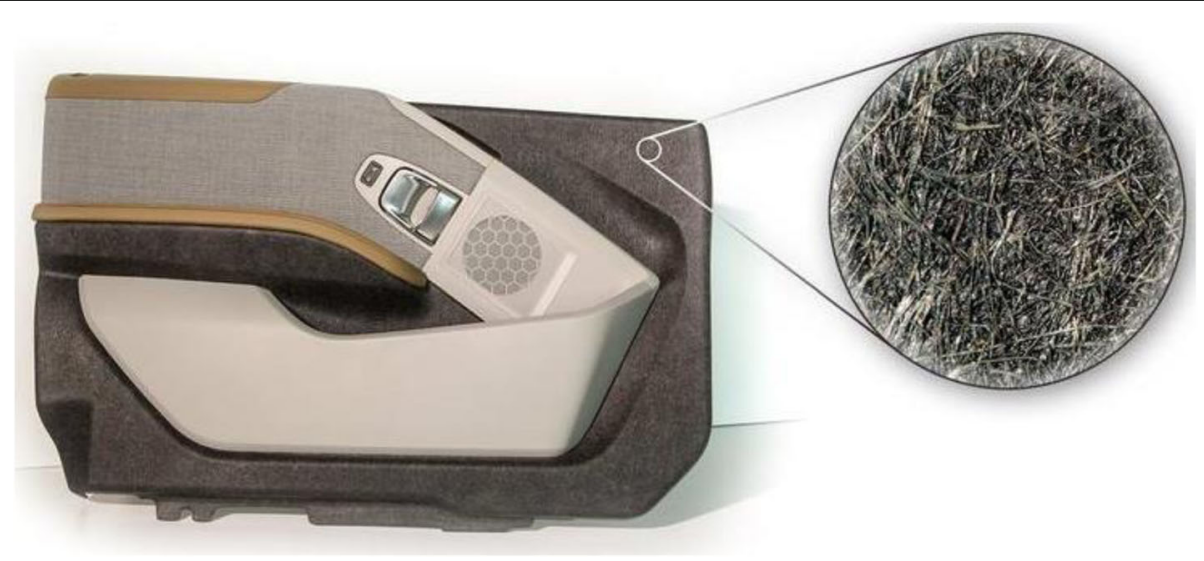

Fig. 4 Untreated door panel with natural materials. Source: DräxImaier, 2018 
Aspects which should be fulfilled by sustainable and natural materials in the interior $(n=141)$

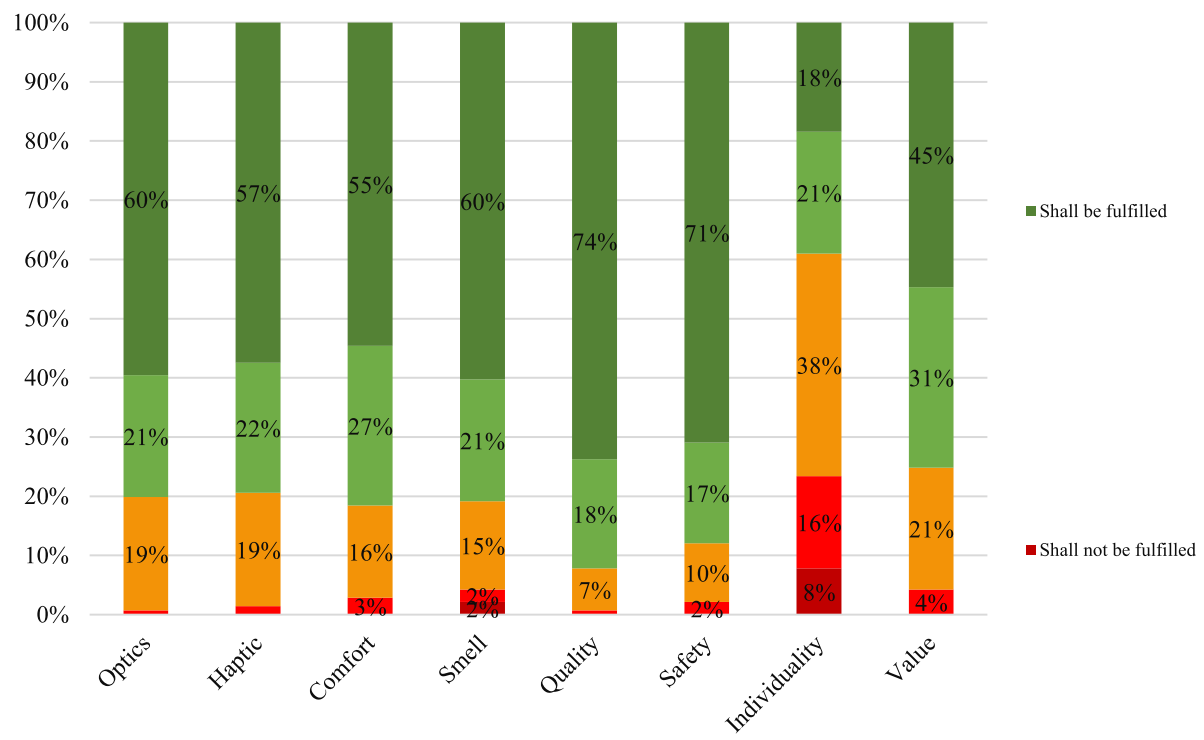

Fig. 5 Aspects that should be fulfilled by sustainable and natural materials in the interior. Source: Own illustration

thus prophesizing an increase in meaning and relevance in the coming years (see Fig. 10).

Overall, it can certainly be seen that the issue of sustainability is present in people's awareness. A tendency towards greater openness for new, more sustainable materials among customers of premium automobiles is recognizable. The priority for customers is that sustainability is taken into account in manufacturing and production, but not to the detriment of appearance, feel, comfort or price.

\section{Discussion of the results}

While there is an agreement in business practice that sustainability is not just a short-term fashion trend, but also a permanent indicator, this is not fully backed up by the empirical results. Only $50 \%$ of the respondents agree with this statement. The cost factor, which, according to the OEM, would have to be compensated, is an obstacle for approximately $50 \%$ of the customers. This means that for every second respondent a conflict of objectives with the OEM exists.

All participants principally agree that sustainability should play an overall role in the automobile and should not be restricted to individual areas. Although the majority of respondents chose the modules power unit and electronics, the category "everywhere" follows close behind in terms of importance. Therefore, the interior as a single module

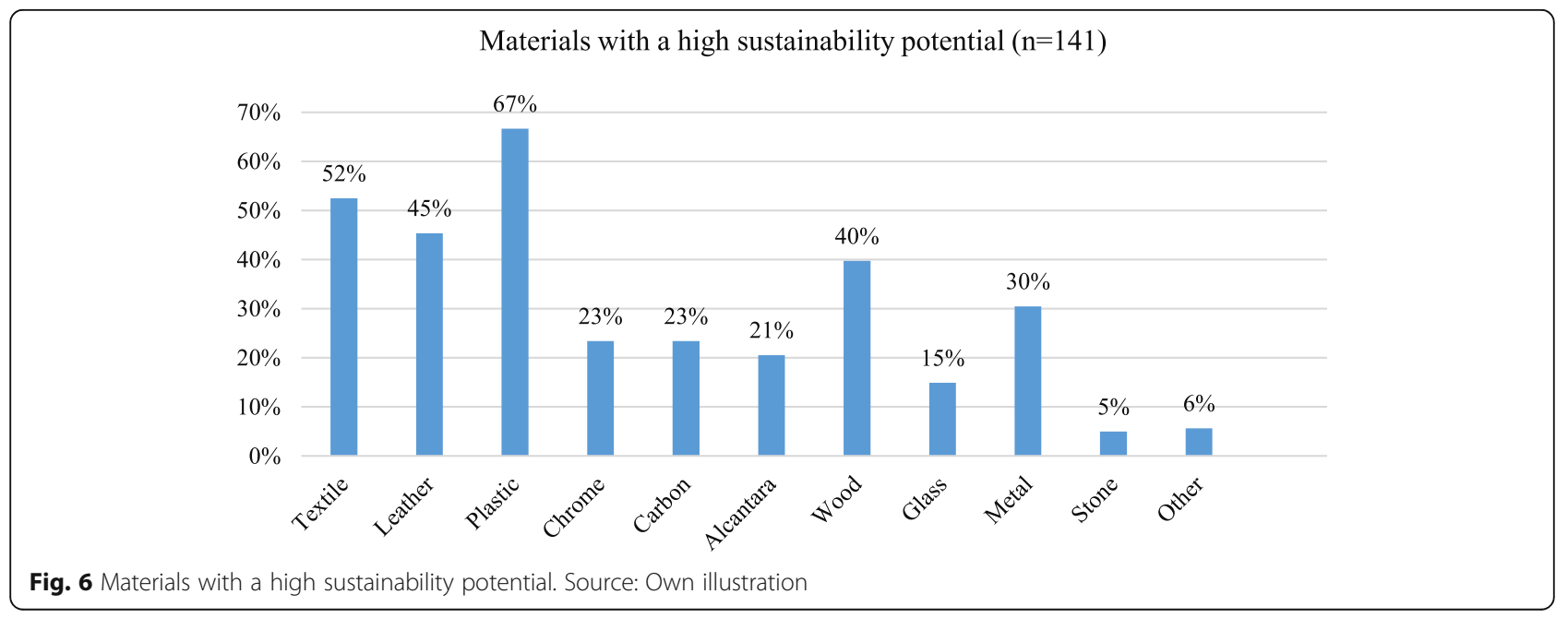




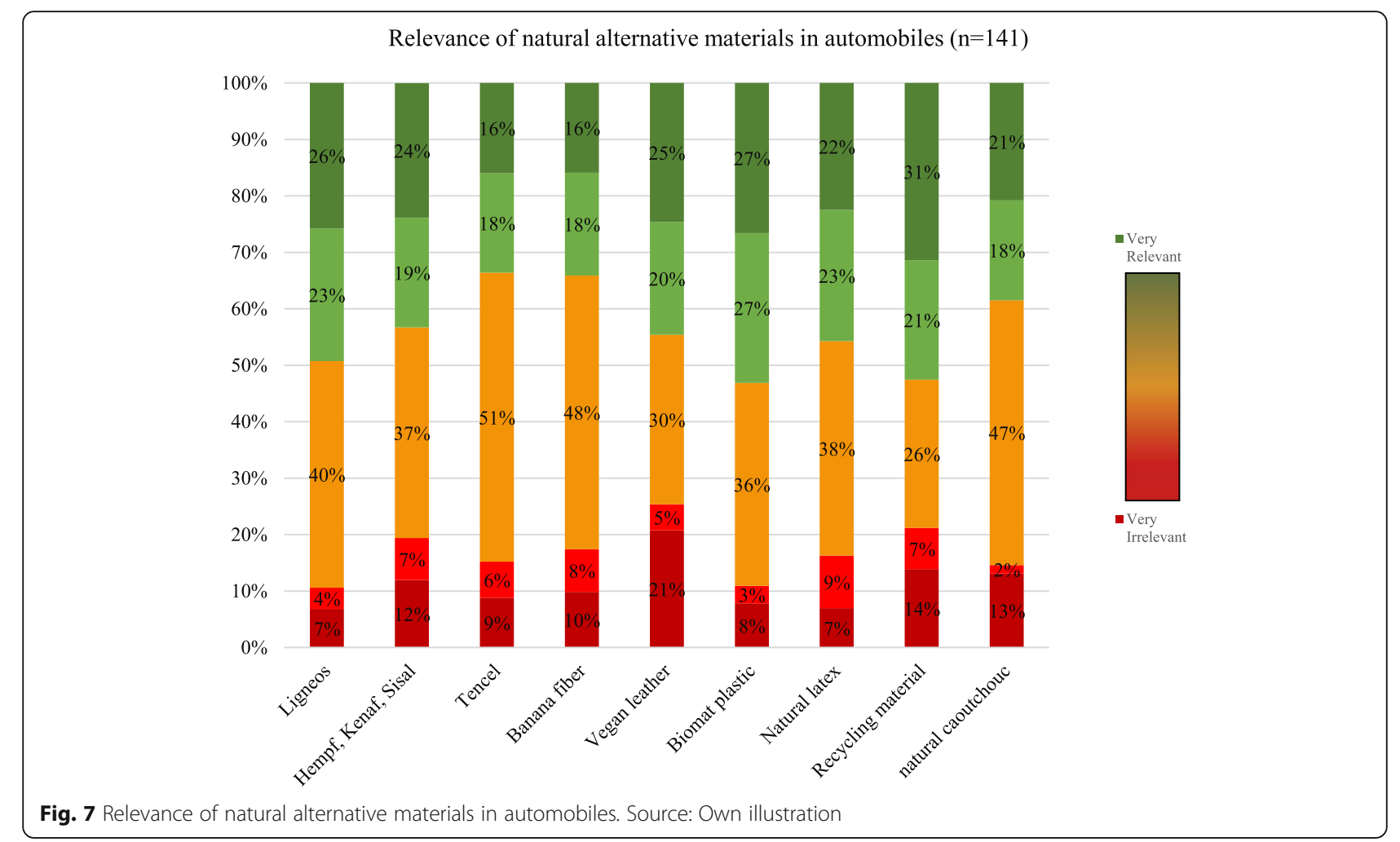

has to be integrated into the overall automotive design.

The customers also highlight that all traditional criteria connected to automobiles - especially appearance, haptics, comfort, smell, quality, safety and value - must also be fulfilled in a sustainable interior. At this point, manufacturers often see a problem. Natural materials fulfil certain properties, but others sometimes not. Consequently, manufacturers need to look more closely at this issue in order to satisfy the wishes of their customers.

As seen in the empirical study, the majority of participants can imagine a centre console made of ligneous wood or a door panel made of natural fibres such as hemp or kenaf. In addition, the topic of recycling is important for the customers. Therefore, the manufacturers should begin to work on innovative solutions regarding this topic.

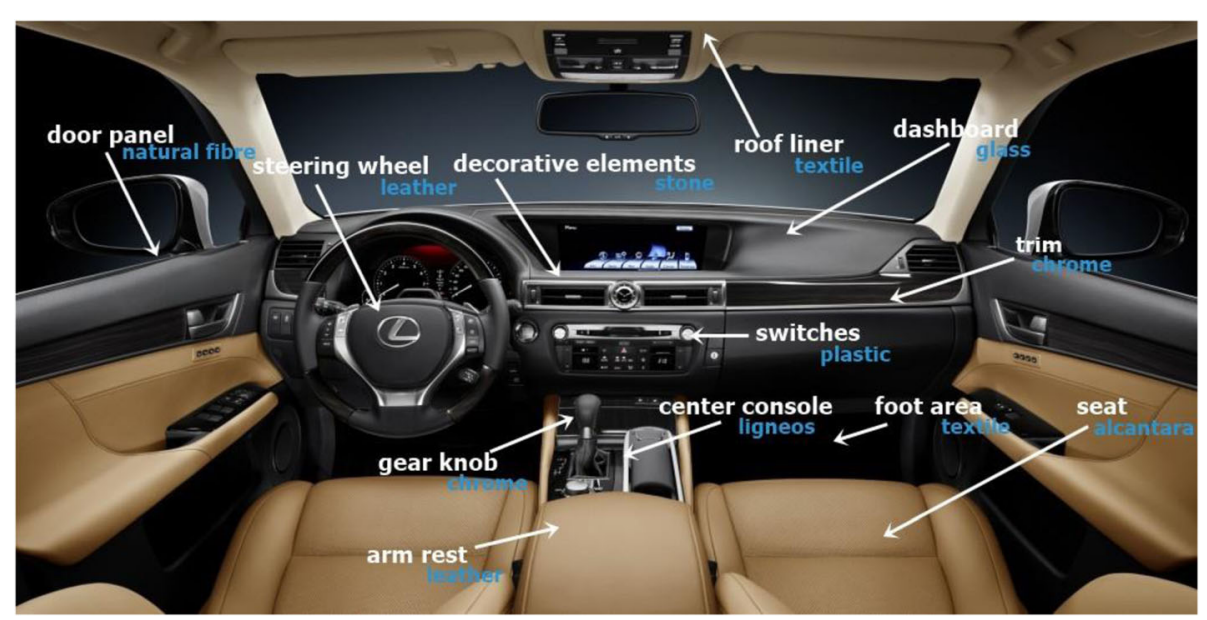

Fig. 8 Interior components with corresponding materials. Source: Barnes-Clay, 2012 


\section{Assessment of the perceptibility of natural materials compared to conventional materials used in the interior $(n=141)$}

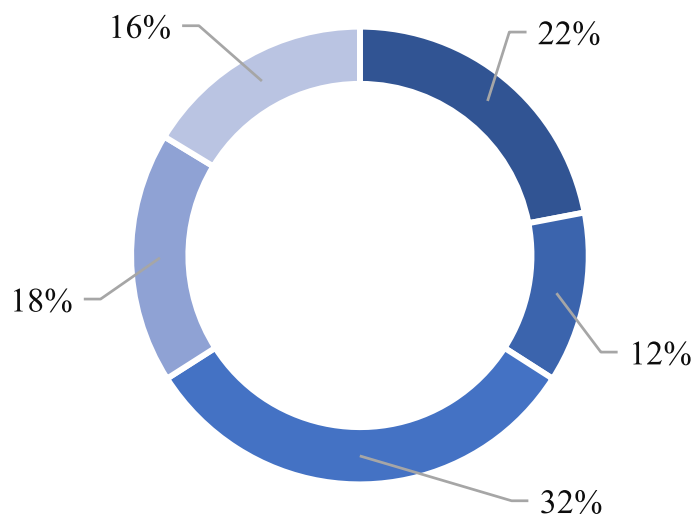

- Should not be noticeable

$-$

- Neutral

$+$

Sustainability should be reflected

Fig. 9 Assessment of the perceptibility of natural materials in the interior. Source: Own illustration

The majority of customers also see an increase in the importance of sustainability for the interior on the horizon. It is therefore crucial for manufacturers to be innovative, show initiative, take advantage of emerging market opportunities and to act proactively. The focus should be on achieving first mover advantages, and it is crucial for OEMs to maintain their position as technology leaders and premium manufacturers, both in Germany and beyond. Therefore, it is imperative that premium manufacturers concentrate on the existing mega-trend of sustainability (Gelowicz et al., 2017; Schade, Zanker, Kühn, \& Hettesheimer, 2014; Skala-
Gast, 2012) and especially take more efforts on sustainable automotive interior solutions. However, all against the background that costumers accept compromises in comfort, practicality and price only to a very limit extend.

Referring to previous research in this area, the paper adds new insights to the topic of customer requirements regarding automotive sustainability in general and sustainable automotive interior in detail. The main result of the paper is to provide further details on the connection between sustainability and customer comfort in the automobile industry and to confront the needs of the

\section{Future importance of natural materials for the interior $(n=141)$}

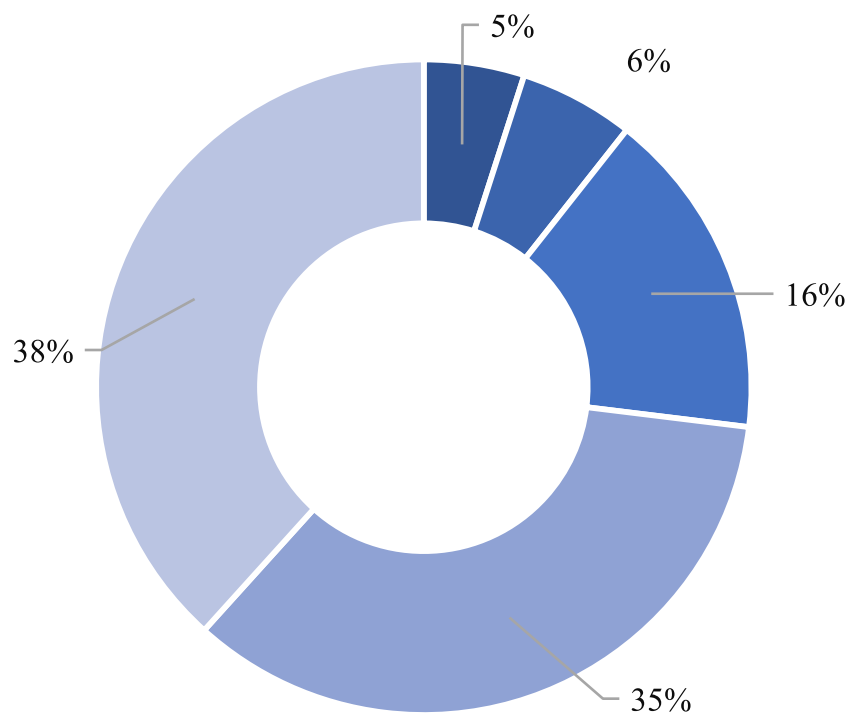

- Unimportant

- -

- Neutral

$+$

Important

Fig. 10 Future importance of natural materials for the interior $(n=141)$. Source: Own illustration 
customers with the challenges of the companies. This made an important contribution to the research field sustainability in the automotive industry.

\section{Conclusion}

The automotive industry is a prime example of small steps bringing change and contributing to a more environmentally friendly world. Suppliers are working with manufacturers to find solutions for a more sustainable interior and the importance of implementing sustainability along the entire supply chain is also well known to those involved. As a result, technological progress and the refinement of processes for the development of natural fibre products make it possible to replace products that currently pollute the environment more simply and cost-effectively with more environmentally friendly products, and at the same time to produce them in a more environmentally friendly way (Dunne et al., 2016; Hetterich et al., 2012).

This article focuses exclusively on premium manufacturers and their customers. The further research project will analyse whether there are significant differences when it comes to volume manufacturers. Furthermore, no distinction has been made between age, gender and automotive brand. Another limitation is the purposive sample of the study. The participants were mainly students, which cannot be taken as an average of the population. All of these will be explored in further research activities.

\section{Abbreviations \\ OEM: Original Equipment Manufacturers; IAC: International Automotive Manufacturers}

\section{Acknowledgements}

Not applicable.

\section{Authors'information}

Prof. Dr. Wanja Wellbrock is a professor for procurement management at Heilbronn University. His main research areas are supply chain management, strategic procurement management, sustainability and big data applications in cross-company value chains. He is the author of various English-and German-language publications and project manager of several practiceoriented research projects in these areas. Prof. Dr. Wanja Wellbrock gained practical experience in management positions in the automotive and aviation industries as well as in management consulting.

Since 2015, Prof. Dr. Daniela Ludin holds the professorship for general business administration at the Heilbronn University of Applied Sciences in the Faculty of Management and Sales on the Schwäbisch Hall campus. To anchor the principle of sustainability as a central moment in her courses is one of her main targets. Since 2017, Prof. Dr. Daniela Ludin is responsible for the Bachelor's degree programm Management \& Procurement Management (B.A. MBW); since 2019 also fort he Bachelor's degree programm Sustainable Procurement Management (B.A. NBW). Since 2015, Prof. Dr. Daniela Ludin is also a member of the Council for Sustainable Development at Heilbronn University, which she has also chaired as Sustainability Officer at Heilbronn University since 2019. Before her time at Heilbronn University, Prof. Dr. Daniela Ludin worked from 2009 to 2015 at the Rottenburg University of Applied Sciences with a professorship for law, environmental and forest policy. Her main research areas are sustainable procurement management, sustainable mobility, sustainable consumption, sustainable financial products and sustainable data management.
Prof. Dr. Wolfgang Gerstlberger is currently Professor of Operations Management at the Tallinn University of Technology (Estonia). Previously, he was Associate Professor for Innovation Management at the University of Southern Denmark in Odense and Endowed Professor for Innovation Management and SME Research at the International University Institute of the Technical University of Dresden. Professor Gerstlberger completed his doctorate and habilitation in the field of general business administration at the University of Kassel. In addition, he has led and carried out numerous innovation and sustainability projects for companies, the EU, associations and public administration organizations as a freelancer. His current research interests are in the areas of sustainable innovation and operations management, digitization and sustainable logistics.

Linda Röhrle finished her Bachelor degree in Management and Procurement Management at the Heilbronn University of Applied Sciences.

\section{Authors' contributions}

Wanja Wellbrock and Linda Röhrle analyzed and interpreted the survey data. Daniela Ludin performed the general sustainability background and Wolfgang Gerstlberger the sustainability aspects regarding automotive interior. All authors were major contributors in writing the manuscript. All authors read approved the final manuscript.

\section{Funding}

Open Access funding enabled and organized by Projekt DEAL.

\section{Availability of data and materials}

The datasets used and/or analysed during the current study are available from the corresponding author on reasonable request.

\section{Competing interests}

The authors declare that they have no competing interests.

\section{Author details}

${ }^{1}$ Heilbronn University of Applied Sciences, Campus Schwäbisch Hall, Faculty of Management and Sales, Heilbronn, Germany. ${ }^{2}$ Department of Business Administration, Tallinn University of Technology, School of Business and Governance, Tallinn, Estonia.

Received: 10 September 2020 Accepted: 13 December 2020 Published online: 30 December 2020

\section{References}

Adekomaya, O., Jamiru, T., \& Sadiku, R. (2016). A review on the sustainability of natural fiber in matrix reinforcement - A practical perspective. Journal of Reinforced Plastics and Composites, 35(1), 3-7.

Avezedo, S., \& Barros, M. (2017). The application of the triple bottom line approach to sustainability assessment. The case study of the UK automotive supply chain. Journal of Industrial Engineering and Management, 10(2), 286-322.

Avezedo, S., Carvaho, H., Duarte, S., \& Cruz-Machado, V. (2012). Influence of green and lean upstream supply chain management practices on business sustainability. IEEE Transaction on Engineering Management, 59(4), 753-765.

Barnes-Clay, T. (2012). Review: Lexus GS 450H hybrid. http:// bloodsweatandfashion.com/lexus-gs-450h/. Accessed 29 Aug 2018.

Bergenwall, A. L., Chen, C., \& White, R. E. (2012). TPS's process design in American automotive plants and its effects on the triple bottom line and sustainability. International Journal of Production Economics, 140(1), 374-384.

Biju, P. L., Shalij, P. R., \& Prabhushankar, G. V. (2015). Evaluation of customer requirements and sustainability requirements through the application of fuzzy analytic hierarchy process. Journal of Cleaner Production, 108, 808-817.

Bjurenstedt, A., \& Lärneklint, F. (2004). 3D biocomposite for automotive interior parts. Lulea: Lulea University of Technology.

Bröker, T., \& Ostner, D. (2017). Innere Leichtigkeit. Automobil Industrie, 62(8), 94-95.

Dannenberg, J. (2017). Auf Einkaufstour. Automobil Industrie, 62(6), 8-12.

Dölle, J. E. (2013). Lieferantenmanagement in der Automobilindustrie. Struktur und Entwicklung der Lieferantenbeziehungen von Automobilherstellern. Wiesbaden: Springer.

DräxImaier (2018). Türverkleidungen. Innovativ und nachhaltig. https:// www.draex/maier.com/produkte/interieur/tuerverkleidungen/. Accessed 29 Aug 2018. 
Dunne, R., Desai, D., Sadiku, R., \& Jayaramudu, J. (2016). A review of natural fibres, their sustainability and automotive applications. Journal of Reinforced Plastic \& Composites, 35(13), 1041-1050.

Focus (2012). Natürliche Sache. https://www.focus.de/auto/news/oekomaterialien-im-auto-innenraum-natuerliche-sache-aid-758345.html. Accessed 29 Aug 2018.

Gelowicz, S., Günnel, T., Hammer, H., \& Otto, C. (2017). Mehr als Werkstoffe. Automobil Industrie, 62(5), 34-37.

Hassan, F., Zulkifli, R., Ghazali, M. J., \& Azhari, C. H. (2017). Kenaf fiber composite in automotive industry: An overview. International Journal on Advanced Science, Engineering and Information Technology, 7(1), 315-321.

Hetterich, J., Bonnemeier, S., Pritzke, M., \& Georgiadis, A. (2012). Ecological sustainability. A customer requirement? Evidence from the automotive industry Journal of Environmental Planning and Management, 55(9), 1111-1133.

Hull, D., \& Clyne, T. W. (1996). An introduction to composite materials, (2nd. ed., ). Great Britain: Cambridge solid state science series.

Industrie, A. (2017). Optimierte, leichtere Komponenten. Automobil Industrie, 62(5), 52.

Jasiński, D., James, M., \& Kerry, K. (2016). A comprehensive framework for automotive sustainability assessment. Journal of Cleaner Production, 135 1034-1044

Karus, M., \& Kaup, M. (2002). Natural fibres in the European automotive industry. Journal of Industrial Hemp, 7(1), 119-131.

Koers, M. (2014). Industrie und Politik. Zusammenspiel als Basis profitablen Wachstums in der Automobilindustrie. In B. Ebel, \& M. B. Hofer (Eds.), Automotive Management. Strategie und Marketing in der Automobilwirtschaft, (2nd ed., pp. 177-188). Berlin et al.: Springer.

Kumar, N., \& Das, D. (2016). Fibrous biocomposites from nettle (Giardinia diversifolia) and poly (lactic acid) fibers for automotive dashboard panel application. Composites Part B Engineering, 130(1), 54-63.

Laukart, G., \& Vorberg, T. (2016). Fahrzeuginnenausstattung. In S. Pischinger, \& U. Seiffert (Eds.), Vieweg Handbuch Kraftfahrzeugtechnik, (8th ed., pp. 714-727). Wiesbaden: Springer.

Mayyas, A., Qattawi, A., Omar, M., \& Shan, D. (2012). Design for sustainability in automotive industry: A comprehensive review. Renewable and Sustainable Energy Reviews, 16(4), 1845-1862

Mcauley, J. W. (2003). Global sustainability and key needs in future automotive design. Environmental Science \& Technology, 37(23), 5414-5416.

Mittelstaedt, J. D., Shultz II, C. J., Kilbourne, W. E., \& Peterson, M. (2014). Sustainability as megatrend. Two schools of macromarketing thought. Journal of Macromarketing, 34(3), 253-264.

Moisescu, O. I. (2018). From perceptual corporate sustainability to customer loyalty: A multi-sectorial investigation in a developing country. Economic Research-Ekonomska Istraživanja, 31(1), 55-72.

Nunes, B., \& Benett, D. (2010). Green operations inititiatives in the automotive inudstry. Benchmarking An International Journal, 17(3), 396-420.

Panuju, A. Y. T., Ambarwati, D. A. S., \& Susila, M. D. (2020, May). Implications of automotive product sustainability on young customers' purchase intention in developing countries: An experimental approach. IOP Conference Series: Materials Science and Engineering, 857(1), 012024.

Pein, M., Laukart, V., Feldmann, D. G., \& Krause, D. (2006). Concepts for energy absorbing support structures and appropriate materials. In Proceedings of the 22nd International Congress of Aeronautical Sciences.

Pischinger, S., \& Seiffert, U. (2016). Ausblick. Wo geht es hin. In S. Pischinger, \& U. Seiffert (Eds.), Vieweg Handbuch Kraftfahrzeugtechnik, (8th ed., pp. 1391-1393). Wiesbaden: Springer.

Puglia, D., Biagiotti, J., \& Kenny, J. M. (2005). A review on natural fibre-based composites-Part II: Application of natural reinforcements in composite materials for automotive industry. Journal of Natural Fibers, 1(3), 23-65.

Schade, W., Zanker, C., Kühn, A., \& Hettesheimer, T. (2014). Sieben Herausforderungen für die deutsche Automobilindustrie. Strategische Antworten im Spannungsfeld von Globalisierung, Produkt- und Dienstleistungsinnovationen bis 2030. Baden-Baden: Edition sigma.

Schmiedel, I., Barfuss, G. S., Nickel, T., \& Pfeufer, L. (2014). Einsatz sichtbarer Naturfasern im Fahrzeuginterieur. Automobiltechnische Zeitschrift, 116(6), 34-37.

Sinha, P., Muthu, S. S., Taylor, I., Schulze, R., Beverley, K., Day, C., \& Tipi, N. (2015) Systems thinking in designing automotive textiles. Textiles and Clothing Sustainability, 1(6), 1-13.

Skala-Gast, D. (2012). Zusammenhang zwischen Kundenzufriedenheit und Kundenloyalität. Eine empirische Analyse am Beispiel der deutschen Automobilindustrie. Wiesbaden: Springer.
Sopher, S. R. (2008). Automotive interior material recycling and design optimization for sustainability and end of life requirements. Society of plastics engineers (SPE)-global plastic and environment conference (GPEC). 2008.

Suddell, B. (2008). Industrial fibres: Recent and current developments. In Proceedings of the symposium on natural fibres, Rome, Italy, 20 October 2008 , (pp. 71-82).

Sullins, T. L. (2013). Biocomposite material evaluation and processing for automotive interior components. Birmingham: University of Alabama.

Thun, J.-H., \& Hoenig, D. (2011). An empirical analysis of supply chain risk management in the German automotive industry. International Journal of Production Economics, 137(1), 242-249.

Verma, D., Gope, P. C., \& Shandilya, A. (2012). Coir fibre reinforcement and application in polymer composites: A review. Journal of Materials and Environmental Science, 4(2), 263-276.

Wallentowitz, H., \& Leyers, J. (2014). Technologietrends in der Fahrzeugtechnik. Dimensionen, Verläufe und Interaktionen. In B. Ebel, \& M. B. Hofer (Eds.), Automotive Management. Strategie und Marketing in der Automobilwirtschaft, (2nd ed., pp. 29-56). Berlin et al.: Springer.

Yanfeng (2017). Naturfasertechnologie von Yanfeng Automotive Interiors trifft den Zeitgeist. https://www.yfai.com/de/naturfasertechnologie-von-yanfengautomotive-interiors-trifft-den-zeitgeist. Accessed 29 Aug 2018.

You, H., Ryu, T., Oh, K., Yun, M. H., \& Kim, K. J. (2006). Development of customer satisfaction models for automotive interior materials. International Journal of Industrial Ergonomics, 36(4), 323-330.

\section{Publisher's Note}

Springer Nature remains neutral with regard to jurisdictional claims in published maps and institutional affiliations.

\section{Submit your manuscript to a SpringerOpen ${ }^{\circ}$ journal and benefit from:}

- Convenient online submission

- Rigorous peer review

- Open access: articles freely available online

- High visibility within the field

- Retaining the copyright to your article

Submit your next manuscript at $\boldsymbol{\nabla}$ springeropen.com 